\title{
Crustal controls on noble gas signatures in fluid inclusions from Andean eruptive products
}

\author{
J. LAGES $^{1 *}$, A.L. RIZZO ${ }^{2}$ AND A. AIUPPA ${ }^{1}$
}

${ }^{1}$ DiSTeM, Univ. of Palermo, 90123 Palermo, Italy (*correspondence: joaopedro.nogueiralages@unipa.it); ${ }^{2}$ INGV - Sezione di Palermo, 90146 Palermo, Italy

Scaling major volatiles to other noble gas tracers, like He, provides important constraints on geochemical cycles along volcanic arcs. Here we report on the characterization of fluid inclusions (FIs) chemistry in olivine and pyroxene (opx and cpx) from Andean eruptive products. Reventador, Cotopaxi and Tungurahua (Ecuador) yield ${ }^{3} \mathrm{He} /{ }^{4} \mathrm{He}\left(\mathrm{R}_{\mathrm{C}} / \mathrm{R}_{\mathrm{A}}\right)$ ratios between 7.0-7.4 $\mathrm{R}_{\mathrm{A}}\left(\mathrm{MORB} \approx 8 \pm 1 \mathrm{R}_{\mathrm{A}}\right)$ in olivine. These were consistently higher than those obtained in their cogenetic opx pairs with lower gas contents and those of free gases reported in literature. Fissure lavas analyzed for Nevado del Ruiz also yield the highest yet ${ }^{3} \mathrm{He} /{ }^{4} \mathrm{He}$ reported $\left(8.5 \pm 0.3 \mathrm{R}_{\mathrm{A}}\right)$ for this volcanic system, which is in the range of fumarolic gas data for Galeras (measured in this study as high as $8.3 \pm 0.1 \mathrm{R}_{\mathrm{A}}$. Clinopyroxenes from Peru showed maximum ${ }^{3} \mathrm{He} /{ }^{4} \mathrm{He}$ ratios between 6.0-6.4 $\mathrm{R}_{\mathrm{A}}$ (for Ubinas, Sabancaya and El Misti), whereas olivine phenocrysts from Villarica yield maximum $\mathrm{R}_{\mathrm{C}} / \mathrm{R}_{\mathrm{A}}$ of $6.7 \pm 0.1$.

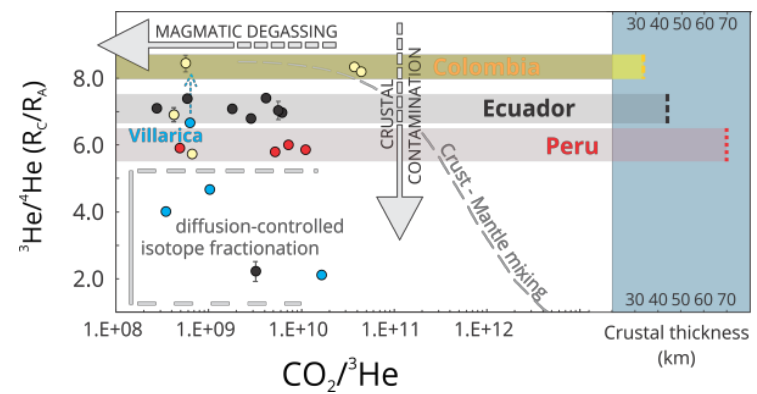

Figure 1: $\mathrm{CO}_{2} /{ }^{3} \mathrm{He}$ vs. ${ }^{3} \mathrm{He} /{ }^{4} \mathrm{He}$ ratios in FIs from Andean products and along-arc crustal thickness variations.

$\mathrm{CO}_{2} /{ }^{3} \mathrm{He}$ ratios systematically higher than the MORB avg. suggest the effect of increasing crustal contamination from Colombia to Peru, synchronously to increasing crustal thicknesses under the respective arc regions, from $<30$ to $>70$ $\mathrm{km}$. Therefore, this study suggests that lower ${ }^{3} \mathrm{He} /{ }^{4} \mathrm{He}$ ratios southward may be a result of prolonged assimilation of radiogenic ${ }^{4} \mathrm{He}$ from the surrounding crust occurring as magma ascends through segments of exceptionally thick continental crust, and underlines the sensitivity of $\mathrm{He}$ in identifying and assessing crustal contamination processes. 